\title{
ANALISIS PERMINTAAN KEDELAI DI INDONESIA
}

\author{
Septi Rostika Anjani, Dwidjono Hadi Darwanto dan Jangkung Handoyo Mulyo \\ Ekonomi Pertanian, Fakultas Pertanian, Universitas Gadjah Mada \\ Email : septirostika@gmail.com
}

\begin{abstract}
This study aims to analyze the factors that influence the demand of soybean in Indonesia. The research method uses descriptive analysis of secondary data which includes the price of imported soybeans, the price of chicken, per capita income, the rate of inflation and import tariff policy year period 1980-2013 which sourced from $F A O$ and other sources. Estimation of demand function using multiple linear regression analysis were transformed in the form of natural logarithm. Regression analysis showed that soybean demand in Indonesia was influenced partially by prices of chicken, per capita income, and the rate of inflation. The price elasticity of demand of soybean in Indonesia is inelastic, that is equal 0,22. While the income elasticity of demand for soybeans is positive which means that soy is a staple item for the Indonesian people.
\end{abstract}

Keywords: demand analysis, elasticity,soybean

\begin{abstract}
Abstrak : Penelitian ini bertujuan untuk menganalisis faktor-faktor yang mempengaruhi permintaan kedelai di Indonesia. Metode penelitian menggunakan analisis deskriptif dari data sekunder yang meliputi harga kedelai impor, harga ayam, pendapatan per kapita, tingkat inflasi dan impor kebijakan tarif periode tahun 19802013 yang bersumber dari FAO dan sumber-sumber lain. Estimasi fungsi permintaan menggunakan analisis regresi linier berganda diubah dalam bentuk logaritma natural. Analisis regresi menunjukkan bahwa permintaan kedelai di Indonesia dipengaruhi sebagian oleh harga dari ayam, pendapatan per kapita, dan tingkat inflasi. Elastisitas harga permintaan kedelai di Indonesia adalah inelastis, yaitu sebesar 0,22. Sementara elastisitas pendapatan dari permintaan untuk kedelai adalah positif yang berarti bahwa kedelai adalah barang pokok bagi masyarakat Indonesia.
\end{abstract}

Kata kunci: analisis permintaan, elastisitas, kedelai

\section{PENDAHULUAN}

Indonesia merupakan salah satu negara agraris terbesar yang memiliki kekayaan alam dimana salah satu diantaranya adalah sektor pertanian. Sejak awal, pengembangan sektor pertanian dianggap strategis di Indonesia. Hal ini disebabkan karena wilayah daratan Indonesia yang sangat luas dan ditunjang oleh struktur geografis yang beriklim tropis sehingga sangat mendukung untuk pembudidayaan berbagai komoditi pertanian, salah satunya adalah kedelai.Di sisi lain, keadaan ini menuntut kebijakan pemerintah pada sektor pertanian disesuaikan dengan keadaan dan perkembangan yang terjadi dilapangan dalam mengatasi berbagai persoalan yang menyangkut kesejahteraan bangsa.

Sejak perdagangan kedelai lepas dari kontrol BULOG pada tahun 1991, impor kedelai meningkat sangat pesat (Sudaryanto dan Swastika, 2007). Produksi kedelai dalamnegeri saat ini hanya mampu memenuhi sekitar 30\% konsumsi domestik, sedangkan sisanya harus diperoleh melalui impor. Impor kedelai diperkirakan akan makin besar pada tahun-tahun mendatang karena adanya kemudahan tataniaga impor sebagaimana yang telah disebutkan diatas bahwa dihapusnya monopoli BULOG sebagai importir tunggal serta dibebaskannya bea masuk dan pajak pertambahan nilai (PPN) kedelai. Disamping 
itu, negara eksportir kedelai terbesar dunia, seperti Amerika Serikat, juga menyediakan subsidi ekspor sehingga merangsang importir kedelai di Indonesia untuk memanfaatkan fasilitas itu.Permintaan kedelai menunjukkan kenaikan yang cukup besar seiring dengan pertambahan jumlah penduduk dan pendapatan masyarakat. Namun, disisi lain kemampuan produksi kedelai didalam negeri belum mampu mencukupi kenaikan permintaan tersebut (Manurung,2002).

Melihat semakin besarnya permintaan dalam negeri yang tidak dapat dipenuhi oleh produksi dalam negeri menuntut pemerintah untuk mengambil langkah impor guna menstabilkan keadaan pasar. Peningkatan jumlah impor dapat dilihat pada tabel 1 yang menggambarkan keadaan impor pada 5 (lima) tahun terakhir.

Besarnya permintaan dalam negeri membuat fluktuasi impor yang cenderung meningkat dari tahun ke tahun. Fluktuasi peningkatan terbesar terjadi pada tahun 2011 dan 2013 yang mana jumlah impor meningkat lebih dari $15 \%$ tahun sebelumnya sebesar 1,7 juta ton atau senilai US\$ 1.244 .307 menjadi sebesar 2 juta ton dengan nilai US\$ 1.244.307.Hal ini menunjukkan bahwa Indonesia menjadi salah satu negara importir kedelai terbesar di Asia Tenggara.

Ketidakmampuan kedelai lokal untuk memenuhi kebutuhan kedelai didalam negeri menyebabkan pasokan kedelai didalam negeri bergantung pada impor kedelai.Ketergantungan yang semakin besar pada impor tentu saja merugikan industri pengolahan kedelai terutama jika harga pangan dunia menjadi sangat mahal akibat stok menurun.Hal ini terjadi karena harga yang berlaku pada kedelai impor mengikuti harga yang berlaku pada harga kedelai internasional (Y.Rante, 2013).
Besarnya ketergantungan terhadap kedelai impor tersebut menyebabkan harga kedelai di pasar cenderung fluktuatif dan sulit untuk dikendalikan oleh instansi terkait. Pada hakikatnya, impor tidak hanya tergantung pada jumlah produksi atau pun pendapatan. Ada faktor lain yang juga mempengaruhi seperti selera dan preferensi konsumen, daya saing produksi dalam negeri, dan sebagainya. Adanya perubahan faktor-faktor tersebut akan menggeser fungsi impor. Seperti inflasi yang terjadi di dalam negeri akan menyebabkan daya saing menurun, maka impor akan cenderung naik dan kurva impor bergeser ke atas (Nopirin, 2009).

Pada tahun 2012, Kementrian Pertanian telah meluncurkan "Gerakan Tanam Kedelai Nasional" dalam upaya mempercepat peningkatan produksi kedelai nasional. Kegiatan dan kebijakan yang terkait dengan kegiatan tersebut antara lain adalah peningkatan produksi, perluasan areal tanam, percepatan penyediaan benih dan stabilisasi harga (Direktorat Pangan dan Pertanian, BAPENNAS, 2013).

Dewasa ini, penanganan program kedelai masih relatif rendah bila dibandingkan dengan usaha peningkatan produksi bahan pangan pokok lainnya seperti padi dan jagung. Keterpaduan antara penyediaan sarana produksi, penyuluhan dan teknologi yang sesuai atau teknologi tepat guna, serta partisipasi petani dalam peningkatan produksi masih lemah.Semakin meningkatnya industri pengguna bahan baku kedelai semakin turut pula mendorong tanaman ini menjadi komoditas strategis karena konsumen kedelai terdiri dari lapisan masyarakat terbesar. Mulai tahun 1970-an konsumen tahu dan tempe meluas tidak hanya di pulau Jawa, tetapi ke seluruh pelosok Indonesia.

Tabel 1. Perkembangan Impor Kedelai Indonesia Tahun 2009-2013

\begin{tabular}{ccc}
\hline Tahun & Jumlah (ton) & Nilai (US\$) \\
\hline 2009 & 1.314 .759 & 621.397 \\
2010 & 1.742 .759 & 841.234 \\
2011 & 2.088 .618 & 1.244 .307 \\
2012 & 1.921 .207 & 1.078 .020 \\
2013 & 2.086 .692 & 1.200 .919 \\
\hline
\end{tabular}

Sumber: FAO (2012) dan Deptan (2015), diolah 
Perpindahan penduduk dari pedesaan ke kotakota besar di seluruh Indonesia juga mendorong berkembang pesatnya industri tahu tempe di kota untuk penyediaan lauk yang merupakan sumber protein dengan harga yang sangat terjangkau bagi masyarakat kota termasuk bagi yang berpenghasilan rendah. Perkembangan industri peternakan dan pakan yang menggunakan bungkil kedelai sebagai sumber utama protein juga mendorong laju peningkatan permintaan kedelai.Tujuan dari penelitian ini adalah untuk menganalisisfaktorfaktor yang mempengaruhi permintaan kedelai di Indonesia.

\section{METODE PENELITIAN}

\section{Ruang Lingkup Penelitian}

Untuk menganalisis permintaan kedelai di Indonesia maka variabel dalam penelitian ini dibatasi hanya pada variabel harga kedelai impor, harga daging ayam, pendapatan perkapita, tingkat inflasi dan kebijakan tarif impor sebagai variabel independen dan variabel permintaan kedelai sebagai variabel dependen. Data yang digunakan dalam penelitian ini adalah data time series tahunan selama 34 tahun yaitu periode tahun 1980-2013. Data sekunder diperoleh dari lembaga serta instansi terkait seperti Badan Pusat Statistik, Departemen Pertanian, Food and Agriculture Organization, hasil penelitian, jurnal, literatur serta instansi lainnya yang terkait dengan penelitian ini.

\section{Model Analisis Data}

Model analisis untuk menguji pengaruh faktorfaktor permintaan kedelai di Indonesia menggunakan analisis regresi linier berganda yang telah ditransformasi kedalam bentuk logaritma natural dengan persamaan sebagai berikut:

$\ln Q_{d}=\ln \beta_{0}+\beta_{1} \ln H_{k i}+\beta_{2} \ln H_{a}+\beta_{3} \ln Y+\beta_{4} \ln T_{i}+\beta_{5} D+e$

Dimana:

$Q_{d}:$ Permintaan kedelai

$\alpha \quad$ : Konstanta atau intersep

$b_{1}$ : Koefisien regresi variabel harga kedelai impor

$b_{2} \quad$ Koefisien regresi variabel harga daging ayam $b_{3}$ : Koefisien regresi variabel pendapatan perkapita

$b_{4} \quad$ : Koefisien regresi variabel tingkat inflasi

$b_{5} \quad$ : Koefisien regresi variabel dummy

$H_{k i}$ : Variabel harga kedelai impor

$H_{a}$ : Variabel harga daging ayam

$Y \quad$ : Variabel pendapatan perkapita

$T_{i} \quad$ : Variabel tingkat inflasi

D : Variabel dummy (kebijakan tarif impor)

1 : Diberlakukan tarif impor

0 : Tidak diberlakukan tarif impor

$e \quad$ : Tingkat kesalahan

Persamaan diatas diestimasi dengan menggunakan metode Ordinary Least Square (OLS) dengan pengujian statistic melalui Uji $\mathrm{t}$ dan Uji F serta memperhatikan kemungkinan terjadinya penyimpangan asumsi klasik yaitu multikolinearitas, heteroskedastisitas dan autokorelasi.

\section{HASIL DAN PEMBAHASAN}

\section{Analisis permintaan kedelai}

Hasil analisis regresi pada tabel 2 menunjukkan bahwa variabel independen (harga kedelai impor, harga daging ayam, pendapatan perkapita, tingkat inflasi, dan kebijakan tarif impor) berpengaruh terhadap variabel dependen (permintaan kedelai).

Hasil analisis pada tabel.1 diperoleh nilai F-hitung sebesar 8,406 dan nilai tersebut lebih besar dari nilai F-tabel $(2,460)$. Hal ini berarti bahwa variabel independen secara bersamasama berpengaruh signifikan terhadap permintaan kedelai pada tingkat kepercayaan $95 \%$.

Pada hasil regresi diperoleh nilai $\mathrm{R}^{2}$ sebesar 0,664. Hal ini berarti bahwa $66,4 \%$ variasi variabel dependen (permintaan kedelai di Indonesia) dapat dijelaskan secara bersamasama oleh variabel independen yang diteliti, sedangkan sisanya sebesar $33,6 \%$ dijelaskan oleh variabel lain yang tidak diteliti pada penelitian ini seperti selera, jumlah penduduk, distribusi pendapatan dan lain-lain.

\section{Harga kedelai impor}

Variabel harga kedelai impor tidak menunjukkan pengaruh yang signifikan terhadap permintaan kedelai di Indonesia. 
Septi R. A., Dwidjono H. D. dan Jangkung H. M. : Analisis Permintaan Kedelai di Indonesia ...

Tabel.2 Hasil Analisis Regresi Permintaan Kedelai di Indonesia

\begin{tabular}{|c|c|c|c|c|}
\hline Variabel independen & Koefisien regresi & T-hitung & Signifikan & DW \\
\hline Konstanta & 1,001 & 0,372 & $0,713^{n s}$ & 1,998 \\
\hline Harga kedelai impor & 0,223 & $-1,358$ & $0,185^{n s}$ & \\
\hline Harga daging ayam & 0,257 & $-2,159$ & $0,040 * *$ & \\
\hline Pendapatan perkapita & 1,415 & 4,440 & $0,000 * * *$ & \\
\hline Tingkat inflasi & $-0,217$ & $-2,347$ & $0,026^{* *}$ & \\
\hline Kebijakan tarif impor (dummy) & $-0,132$ & $-1,086$ & $0,287^{n s}$ & \\
\hline Koefisien determinasi $\left(\mathrm{R}^{2}\right)$ & 0,664 & & & \\
\hline F hitung & $10,115^{* *}$ & & & \\
\hline 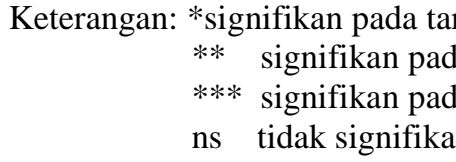 & $\begin{array}{l}\text { kepercayaan } 90 \% \\
\text { araf kepercayaan } 95 \% \\
\text { araf kepercayaan } 99 \%\end{array}$ & & & \\
\hline
\end{tabular}

Adanya ketergantungan terhadap impor kedelai menjadi salah satu faktor tidak berpengaruhnya harga kedelai impor terhadap jumlah permintaan kedelai.Kuantitas kedelai impor yang melebihi kuantitas kedelai lokal membuat harga kedelai impor memiliki pangsa yang cukup besar sehingga jumlah permintaan kedelai tidak terpengaruh oleh harga kedelai itu sendiri.Dalam jangka pendek, solusi yang paling efektif untuk memenuhi kekurangan kedelai dalam negeri adalah mengimpor kedelai. Jadi berapapun harga kedelai impor yang berlaku, pemerintah akan tetap membeli kedelai impor. Hal tersebut dilakukan demi menjamin ketersediaan kedelai bagi rumah tangga untuk dikonsumsi secara langsung dan juga bagi industri yang digunakan sebagai bahan baku untuk menciptakan produk turunan.Oleh karena itu, tinggi atau rendahnya harga kedelai impor yang berlaku tidak memiliki pengaruh terhadap permintaan kedelai di Indonesia.

\section{Harga daging ayam}

Variabel harga daging ayam berpengaruh nyata terhadap permintaan kedelai di Indonesia.Hal ini dapat dilihat dari nilai t hitung yakni sebesar $-2,159$ signifikan pada tingkat $95 \%$. Nilai koefisien regresi sebesar -0,257 mengartikan bahwa apabila harga daging ayam meningkat $1 \%$ maka akan diikuti dengan penurunan permintaan kedelai sebesar $0,257 \%$. Sehingga dapat dikatakan bahwa harga daging ayam yang mengalami penurunanakan berpengaruh nyata secara statistik terhadap permintaan kedelai di Indonesia.

\section{Pendapatan perkapita}

Variabel pendapatan perkapita berpengaruh signifikan terhadap permintaan kedelai di Indonesia.Nilai koefisien regresi variabel pendapatan perkapita sebesar 1,415. Hal ini menunjukkan bahwa apabila pendapatan perkapita meningkat sebesar 1\%, maka permintaan kedelai akan meningkat sebesar $1,415 \%$. Nilai elastisitas dari variabel pendapatan perkapita adalah sebesar 1,415 yang berarti kedelai di Indonesia termasuk barang superior yang merupakan kebutuhan pokok.Salah satu faktor penentu dalam permintaan suatu barang adalah pendapatan. Untuk barang normal berlaku hukum apabila pendapatan meningkat maka masyarakat akan meningkatkan jumlah permintaannya namun dengan persen yang lebih rendah dibandingkan dengan barang mewah atau superior (efek pendapatan positif). Sedangkan untuk barang inferior, apabila pendapatan meningkat maka masyarakat akan menurunkan jumlah permintaannya (efek pendapatan negatif). Hasil analisis regresi pada tabel 2 menunjukkan bahwa pendapatan perkapita memiliki pengaruh yang signifikan terhadap jumlah permintaan kedelai di Indonesia pada tingkat kepercayaan $99 \%$.

\section{Tingkat inflasi}

Koefisien variabel tingkat inflasi menunjukkan adanya pengaruh negatif dan signifikan terhadap permintaan kedelai di Indonesia. Nilai koefisien regresi sebesar -0,217 mengartikan bahwa apabila inflasi meningkat $1 \%$ maka permintaaan kedelai akan menurun sebesar $0,217 \%$ dengan faktor lain dianggap tetap. 


\section{Kebijakan tarif impor (variabel dummy)}

Variabel dummy kebijakan tarif impor tidak menunjukkan adanya pengaruh yang signifikan terhadap jumlah permintaan kedelai di Indonesia. Dalam upaya menjaga stabilitas harga kedelai lokal, dengan tetap memperhatikan kepentingan petani dan konsumen, pada tahun 2013 pemerintah memberlakukan tarif impor (bea masuk) sebesar 0\%. Ketetapan ini tertuang dalam Peraturan Menteri Keuangan Nomor 133/PMK.011/2013 yang ditandatangani oleh Menteri Keuangan pada 3 Oktober 2013. Ketentuan tersebut sekaligus mengubah Peraturan Menteri Keuangan Nomor 213/PMK.011/2011 yang memberikan bea masuk sebesar 5 persen atas impor kedelai. Adanya penetapan tarif impor seharusnya mampu menjaga keseimbangan antara pasokan impor dan produksi dalam negeri.Namun adanya pemberlakuan kebijakan tarif impor belum efektif dan efisien untuk menanggulangi permasalahan permintaan kedelai.Hal ini disebabkan ketergantungan pemerintah terhadap kedelai impor. Ketergantungan ini diakibatkan oleh kenyamanan pemerintah untuk terus mengimpor kedelai disaat produksi kedelai masih dapat dikembangkan.Besarnya ketergantungan terhadap impor berdampak pada tidak adanya upaya peningkatan produksi dan daya saing kedelai.Hal ini menyiratkan bahwa kebijakan tarif impor hanya menguntungkan pihak tertentu. Selain itu, terdapat banyak faktor lain yang lebih berpengaruh terhadap permintaan kedelai seperti harga barang lain yang terkait, faktor selera dan lain-lain.

\section{KESIMPULAN DAN SARAN}

\section{Kesimpulan}

1. Permintaan kedelai di Indonesia dipengaruhi secara positif oleh harga daging ayam dan pendapatan perkapita, serta dipengaruhi secara negatif oleh tingkat inflasi. Sedangkan harga kedelai impor dan kebijakan tarif impor tidak berpengaruh signifikan terhadap permintaan kedelai di Indonesia.

2. Elastisitas harga terhadap permintaan kedelai di Indonesia bersifat inelastis, sedangkan elastisitas harga silang dari kedelai yaitu daging ayam bernilai positif yang berarti bahwa komoditi daging ayam bersifat substitusi bagi komoditi kedelai. Sementara elastisitas pendapatan terhadap komodoti kedelai bernilai positif yang mengartikan bahwa kedelai merupakan barang pokok bagi masyarakat Indonesia.

\section{Saran}

Dari kesimpulan atas hasil analisis penelitian ini, maka saran-saran yang dapat diajukan adalah sebagai berikut:

1. Pemenuhan atas kebutuhan permintaan kedelai yang terus meningkat tidak seharusnya selalu didominasi oleh kedelai impor, sebab dampak jangka panjangnya bagi Indonesia khususnya petani lokal akan merugi secara ekonomi dan melemahkan daya saing kedelai lokal itu sendiri. Oleh karena itu, pemerintah selaku pengampu kebijakan perlu mempertimbangkan berbagai aspek dan dimensi secara komprehensif agar dapat menguntungkan seluruh pihak terkait, terutama petani dan konsumen demi terwujudnya stabilitas perekonomian jangka panjang.

2. Dominasi kedelai impor di dalam negeri perlu diatasi tidak hanya dengan kebijakan tarif impor namun juga perlu campur tangan langsung dari para petani lokal selaku produsen. Oleh karenanya, petani kedelai agar dapat meningkatkan keterampilannya dalam pengelolaan kedelai dengan menerapkan teknologi, metode ataupun bibit unggul yang dapat meningkatkan produksi serta produktivitasnya sehingga dapat memiliki daya saing yang tinggi terhadap kedelai impor yang telah mendominasi tersebut.

3. Penelitian ini memiliki beberapa keterbatasan, oleh karenanya perlu penelitian lebih lanjut mengenai faktorfaktor yang mempengaruhi permintaan dan penawaran terutama mengenai variabelvariabel yang terkait secara langsung seperti proporsi demand dari aspek industri serta jumlah industri yang menghasilkan produk turunan dari komoditi kedelai. 
Septi R. A., Dwidjono H. D. dan Jangkung H. M. : Analisis Permintaan Kedelai di Indonesia ...

\section{DAFTAR PUSTAKA}

Food and Agriculture Organization.2012. Indonesia Soybean Import Quantity.http://faostat.fao.org. diakses pada 15 April 2015

Departemen Pertanian. 2015. Perkembangan Impor Kedelai Indonesia. http://database.pertanian.go.id. diakses pada 15 Mei 2015

Direktorat Pangan dan Pertanian. (2013). Rencana Pembangunan Jangka Menengah Nasional (RPJMN) Bidang Pangan dan Pertanian 2015-2019. BAPENNAS. Jakarta.

Manurung, R.M.H. 2002.Tantangan dan peluang pengembangan tanaman kacangkacangan dan umbi-umbian.hlm.19-40. Risalah Seminar Teknologi Inovatif Tanaman Kacang-kacangan dan Umbiumbian Mendukung Ketahanan Pangan.
Malang, 25-26 Juni 2003.Balai Penelitian Tanaman Kacang-kacangan dan Umbi-umbian, Malang.

Nopirin. 2009. Ekonomi Internasional. Edisi ketiga. BPFE. Yogyakarta.

Rante, Y., 2013. Strategi Pengembangan Tanaman Kedelai Untuk Pemberdayaan Ekonomi Rakyat Di Kabupaten Keerom Provinsi Papua. Jurnal Manajemen Keuangan, Vol.15. hlm.75-88.

Siregar, M. 2003. Kebijakan Perdagangan dan Daya Saing Komoditas Kedelai. PSE Balitbang Pertanian, Deptan RI. Bogor.

Sudaryanto, T.\& Swastika, D. K. S. 2007. Ekonomi Kedelai di Indonesia. Dalam; Sumarno, Suyamto, Widjono, A., Hermanto, K, H., (Eds). Kedelai: Teknik Produksi dan Pengembangan. Badan Penelitian dan Pengembangan Tanaman Pertanian. Bogor. 